\title{
PRE-REGISTRATION POSTS IN PSYCHIATRY
}

The General Medical Council will now allow a period of time to be spent in psychiatry during the pre-registration year. This could consist of a fourmonth period, plus four months of medicine and four months of surgery or, alternatively, a two-month period during a six-month medical post.

The College would like to gather information about the difficulties encountered by members in setting up posts of this nature, as it appears that in many parts of the country local negotiations with medical and surgical colleagues have been unsuccessful.

Letters giving examples of successful posts or details of difficulties encountered would be welcomed and should be addressed to the Registrar.

\section{UNDER DISCUSSION}

\section{Compulsion in emergency?}

Getting the patient to hospital under a Section 29 order is posing unexpected difficulties in some areas. Outside weekday office hours, or at weekends and bank holidays, some Social Service Departments cannot (or will not) provide a social worker as required for completion of the order. In some places the police have been 'arresting' patients and taking them to hospital on a Section 136. In others, patients in casualty who were considered to need hospital treatment were simply let go. General practitioners called out on psychiatric emergencies at night have been complaining of the way they are being frustrated in action they consider necessary. The College has written to the DHSS about this failure to honour the intentions of the Mental Health Act, and the retrogressive step in making compulsory admission a police matter. However, it is not known how widespread these difficulties are, and so the College invites details from members. Social workers do not like doing these duties, and their departments have difficulty, in part financial, in providing 24-hour cover. How should this matter be handled?

\section{Philosophy of Rampton}

The concern over Rampton sparked off by two television programmes, has led to the setting up of two official Inquiries which examine the actual work by the staff there in the detention and treatment of the abnormal offender. It would seem that the time is ripe for a wider look at the functions of the Special Hospitals, last considered in 1961-Broadmoor and Moss Side as well as Rampton. These hospitals used to be under the Home Office, but are now part of the Health Service. Have the implications of this transfer been thought through? What is the role of a Special Hospital, and how does it compare with a Regional Secure Unit, or differ from the psychiatric prison at Grendon Underwood?

Elements of medical diagnosis and therapy, security and containment, possibly punishment and social and moral re-education are involved, and each imposes a work style on the staff. Some review of philosophy and aims seems appropriate.

ONLOOKER

\section{FORTHCOMING EVENTS}

The British Association for Psychopharmacology will hold its Spring Meeting at the Royal Society on 25 April 1980. There will be a symposium on 'Biological Classification of Depressive Illness'. Its annual twoday Summer Meeting will be held at Exeter University on 14 and 15 July 1980 . There will be two symposia entitled 'Sleep' and 'New Antidepressants', and a session devoted to free communications. Any member or non-member who is interested in submitting a free communication, or who needs further details of either meeting should contact Dr David Wheatley, Programme Secretary, 325 Staines Road, Twickenham TW2 5AY.
A one-week course in Child Psychiatry will be held at the Institute of Child Health from 18 to 22 February 1980. The fee is $\mathbf{f 6 0}$ and the closing date for receipt of applications is 2 January 1980 . For further details contact the Sub-Dean, Institute of Child Health, 30 Guilford Street, London WCIN 1 EH.

A two-day course in Family Psychiatry for Psychiatrists will be held on 18 and 19 June 1980, at the Institute of Family Psychiatry, Ipswich. Programmes and application forms are available from the Secretary, The Institute of Family Psychiatry, Ipswich Hospital, 23 Henley Road, Ipswich IP1 3TF. 